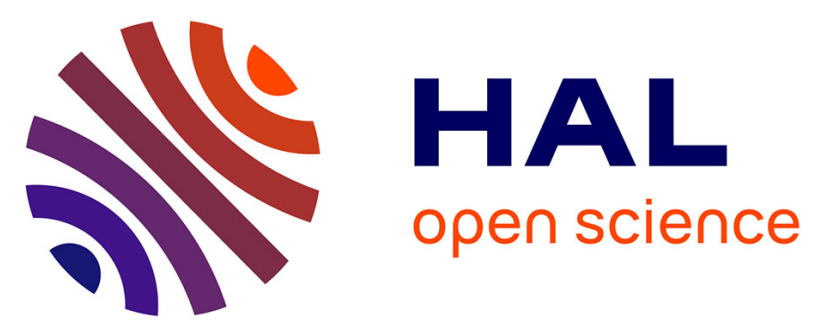

\title{
High prevalence of ST121 in community-associated methicillin-susceptible lineages responsible for skin and soft tissue infections in Portuguese children
}

\author{
T. Conceição, M. Aires-De-Sousa, N. Pona, M. J. Brito, C. Barradas, Rui
} Coelho, T. Sardinha, L. Sancho, G. Sousa, M. Céu Machado, et al.

\section{To cite this version:}

T. Conceição, M. Aires-De-Sousa, N. Pona, M. J. Brito, C. Barradas, et al.. High prevalence of ST121 in community-associated methicillin-susceptible lineages responsible for skin and soft tissue infections in Portuguese children. European Journal of Clinical Microbiology and Infectious Diseases, 2010, 30 (2), pp.293-297. 10.1007/s10096-010-1087-8 . hal-00637791

\section{HAL Id: hal-00637791 https://hal.science/hal-00637791}

Submitted on 3 Nov 2011

HAL is a multi-disciplinary open access archive for the deposit and dissemination of scientific research documents, whether they are published or not. The documents may come from teaching and research institutions in France or abroad, or from public or private research centers.
L'archive ouverte pluridisciplinaire HAL, est destinée au dépôt et à la diffusion de documents scientifiques de niveau recherche, publiés ou non, émanant des établissements d'enseignement et de recherche français ou étrangers, des laboratoires publics ou privés. 
1 High prevalence of ST121 in community associated methicillin-susceptible

2 Staphylococcus aureus lineages responsible for skin and soft tissue infections in

3 Portuguese children

4

5 Teresa Conceição ${ }^{1}$, Marta Aires de Sousa ${ }^{1,2}$, Natália Pona ${ }^{3}$, Maria João Brito ${ }^{3}$, Carlos

6 Barradas $^{3}$, Raquel Coelho ${ }^{3}$, Luísa Sancho ${ }^{4}$, Teresa Sardinha ${ }^{4}$, Germano de Sousa ${ }^{4}$,

7 Maria do Céu Machado ${ }^{3}$, and Hermínia de Lencastre ${ }^{1,5}$

8

$9{ }^{1}$ Laboratory of Molecular Genetics, Instituto de Tecnologia Química e Biológica, 10 Oeiras, Portugal; ${ }^{2}$ Escola Superior de Saúde da Cruz Vermelha Portuguesa, Lisbon,

11 Portugal; ${ }^{3}$ Department of Paediatrics, Hospital Fernando Fonseca, Amadora, Portugal;

$12{ }^{4}$ Laboratory of Microbiology, Hospital Fernando Fonseca, Amadora, Portugal

$13 \quad{ }^{5}$ Laboratory of Microbiology, The Rockefeller University, New York, NY, USA

Keywords: CA-MSSA, SSTI, PVL, children, Portugal

20 Corresponding author. Mailing address: The Rockefeller University, 1230 York Ave.,

21 New York, NY10065. Phone: (212) 327-8278. Fax: (212) 327-8688. E-mail: lencash@mail.rockefeller.edu 


\section{ABSTRACT}

24 In order to evaluate the incidence of CA-MRSA in Portugal, we analyzed a collection 25 of $38 \mathrm{~S}$. aureus isolates recovered from 30 children attending the paediatric 26 emergency department of a central hospital in Lisbon due to skin and soft tissue 27 infections. Molecular characterization identified seven clonal lineages among the 35 28 MSSA isolates, out of which the major lineage PFGE A/t159/ST121 included $63 \%$ of 29 the isolates. The three MRSA isolates belonged to the Paediatric clone - PFGE 30 D/t535/ ST5-IV $(n=2)$ and to the European CA-MRSA clone - PFGE G/ t044/ ST8031 IVc. All isolates harboured several virulence factors, namely leukocidins. PVL was 32 produced by isolates from five MSSA lineages and by the ST80 MRSA. Of interest 33 this is the first reported isolation of CA-MRSA ST80 in Portugal. 
(Body text: 1386 words)

Methicillin resistant Staphylococcus aureus (MRSA) infections in the community have been increasing worldwide and are mainly reported as skin and soft tissues infections (SSTI) in otherwise healthy young individuals [1-3]. The Centers for Disease Control and Prevention (CDC) consider a community associated MRSA (CAMRSA) infection when the patient has no previous history of MRSA infection or colonization, surgery, dialysis, hospitalization, residence in a long-term care facility within the year before infection, presence of a percutaneous device and indwelling catheter and hospitalization $>48 \mathrm{~h}$ before MRSA cultures $[4,5]$.

CA-MRSA isolates differ phenotypically and genotypically from hospital-associated (HA-) MRSA, namely in its non-multiresistant antibiotic patterns, enhanced virulent gene content, including the acquisition of the necrotizing Panton Valentine leukocidin (PVL) genes or expression of $\alpha$-type phenol-soluble modulins (PSMs) [1, 3]. The staphylococcal cassette chromosome mec (SCCmec) type and the accessory gene regulator (agr) alleles are also differentially distributed: SCCmec types IV or V and agr type III are more commonly present in CA-MRSA, while SCCmec types I-III and agr type II are more typical of HA-MRSA [1]. In contrast, community-acquired methicillin susceptible $S$. aureus (CA-MSSA) isolates, responsible for a significant number of mild SSTI, do not differ from HA-MSSA [6, 7].

Although reports of CA-MRSA prevalence are increasing worldwide, there is no description of the actual scenario in Portugal, a country with $>50 \%$ of HA-MRSA infection, currently the highest in Europe [8]. Previous studies dated from 1996 to 2009, including isolates from nasal swabs of young healthy individuals and nasopharyngeal swabs of children attending day care centres, reported a MRSA 
61

62

prevalence lower than $0.25 \%$ in the Portuguese healthy community $(0.24 \%$ in 1996 1998 and $0.13 \%$ in 2006-2009) [6, 9, 10].

It is conceivable that the incidence of CA-MRSA in Portugal is underestimated partially because skin infection samples are not routinely cultured.

The aim of the present study was to assess the prevalence and molecular characterization of $S$. aureus in children attending the paediatric emergency department of a central hospital due to SSTI.

The paediatric emergency department of Hospital Fernando Fonseca, a large tertiary care hospital (670 beds), is the second largest paediatric urgency unit in the urban area of Lisbon, Portugal, and receives approximately 180 children per day. Between August 2005 and October 2006 all children attending this unit due to SSTI were enrolled in the study. Samples were recovered by swabbing the largest area of skin infection or wounds with spontaneous or surgical drainage, or in case of severe SSTI from hemoculture. Whenever possible, nasal swabs were also performed. A questionnaire was filled in order to assemble data on basic socio-demographic patient information, risk factors associated with skin infection, and description of the infection.

S. aureus isolates were first identified by conventional coagulase and catalase tests. Additional identification and susceptibility testing with a panel of 10 antibiotics (Fig. 1) were performed by the semi-automatic VITEK2 system (bioMérieux, SA, France) and disk diffusion method for clindamycin [11]. All isolates were tested by PCR for the presence of mecA [12] and also characterized by PFGE [13]. The resulting SmaI 
patterns were analyzed by both visual inspection and automatically with BioNumerics software version 4.61 (Applied Maths, Sint-Martens-Latem, Belgium) [14, 15]. Characterization by spa typing, multilocus sequence typing (MLST) and the agr allele type were performed on representative isolates of each PFGE type [16-18]. The SCCmec was typed for all MRSA isolates $[19,20]$. Specific staphylococcal virulence determinants, including leukocidins, hemolysins and super-antigenic toxins of each isolate were determined by PCR [21, 22] (Fig. 2). Categorical variables were compared using the $\chi^{2}$ or the Fisher's exact test when appropriated, considering $P$ values of $\leq 0.05$ statistically significant, and Odds Ratio (OD) estimates using SPSS package version 11.5 (SPSS Inc., Chicago, USA).

During the 15-months study period, $30(73.2 \%)$ out of the 41 children that attended the emergency department due to SSTI were infected by S. aureus. The major clinical infection presentations were cutaneous abscesses $(n=12,40 \%)$ and cellulitis $(n=10$, $33.33 \%)$. A total of 38 isolates was recovered, out of which three (7.9\%) were MRSA. Although eight clonal types (Table 1) were identified among the isolates, 63\% $(\mathrm{n}=$ 19) belonged to a single type: PFGE A, spa type t159, sequence type (ST) 121, agr type IV. ST121 lineage was also the predominant lineage found in MSSA isolates through Europe and Russia [23-25] and an identical scenario has been reported among Asiatic children in both carriage and disease isolates, and frequently associated to PVL. Of major concern was the local emergence of methicillin resistance in ST121 isolates in these paediatric communities: one MRSA isolate, PVL negative responsible for staphylococcal scalded skin syndrome in China and two MRSA, PVL positive, SCCmec type $\mathrm{V}$ isolates responsible for osteomyelitis and soft tissue abscess, in Cambodia [26, 27]. Moreover, single ST121 MRSA isolates were reported in China (http://saureus.mlst.net/) and the United States [28]. 
Retrospectively, all STs found in the present study (with the exception of ST152) have already been described in carriage in the Portuguese community in 1996, although with a different prevalence [6]. Despite the small size of the collection, the major CA-MSSA clones described in Europe, ST1, ST5, ST30 and ST45 [29], were found in the paediatric Portuguese community (Table 1). Moreover, all clonal lineages, with the exception of PFGE H/t084/ST582/agrIV, were recently reported among a geographical and temporal diverse collection of 211 PVL-positive CAMSSA [23]. ST1/t127, the sixth more frequent type among MSSA isolates recovered in 26 European countries [29] was also found in the present collection. In the same work, Grundmann et al. showed that European MSSA isolates belonged to more diverse genetic backgrounds and have a wide geographical distribution comparing to MRSA, which have a predominantly regional spread of few pandemic clones [29].

A non-multiresistant antibiotic pattern is common in the present collection (Fig. 1). Clindamycin and trimethoprim-sulfamethoxazole (SXT) are rational empiric choices for mild-to-moderate CA-MRSA infections [30]. However, positive D-test in erythromycin resistant isolates indicates that clindamycin resistance may emerge during therapy and therefore should not be prescribed [31, 32]. The detection of clindamycin inducible resistance in all erythromycin resistant isolates $(n=10)$ raises some concerns about the antibiotherapy available for children treatment, namely since resistance to STX was found in three isolates from children with no previous hospitalization.

As far as we know, the single tetracycline resistant strain, HFF189, was the first MRSA ST80 (known as the European CA-MRSA clone), PVL-positive described in Portugal. Nevertheless, since it was recovered from a periumbilical exudate of a neonate, the connection to the nosocomial setting could not be discarded, as ST80 
134

135

136

137

138

139

140

141

142

143

144

145

146

147

148

149

150

151

152

153

154

155

156

PVL-positive isolates were already described as nosocomial isolates in the late 1990s [33]. Regular surveillance studies in Portuguese hospitals [34] together with the present study seem to indicate that CA-MRSA-ST80 is not widely spread in Portugal in contrast to what was described in several other European countries [21, 35].

Interestingly, the remaining two MRSA isolates, PVL-negative, showed ST5-SCCmec type IV typical of the Paediatric clone, described for the first time in a Portuguese paediatric hospital [36]. The spread in the community of a typical HA-MRSA lineage raises some concern about the changing epidemiology of MRSA, and the blurring of the boundaries between the hospital and the community.

All the isolates presented virulence determinants, namely leukocidins (Fig. 2). Recently, a mechanism of PVL-induced acute lung injury and lung inflammation in rabbit models resolved the controversial about the role of PVL as a key factor in $S$. aureus infection [37]. In our study, isolates producing PVL or $\gamma$-hemolysin were mainly associated to cutaneous abscesses $(P=0.003$ and $P=0.000$, respectively $)$ as already reported in recent studies in children infections [38, 39]. Conversely, production of $\beta$-hemolysin, ETA or ETB seemed to be associated with celullitis $(P=$ $0.010, P=0.003$ and $P=0.038$, respectively) (data not shown).

No significant positive association was found between socio-demographic data or possible risk factors for $S$. aureus infection, possibly due to the small dimension of the collection (data not shown).

MSSA infections, independently of the PVL content, frequently show similar epidemiological and clinical characteristics as MRSA, but specific PVL-positive 
157

158

159

160

161

162

163

164

165

166

167

168

169

170

171

172

173

174

175

176

177

MSSA lineages, are dynamically interrelated and recently reported as reservoirs of CA-MRSA [23, 40]. Therefore, a regular surveillance of SSTI, namely in children, is critical to predict and control the emergence of methicillin resistance and spread of staphylococcal infections in the community.

This work was partially supported by Project POCTI/SAU-ESP/57841/2004 from Fundação para a Ciência e Tecnologia (FCT), Portugal and by funding from the European Community, project TROCAR (FP7-HEALTH-2007-B project $\mathrm{n}^{\circ} 223031$ ). T. Conceição was supported by grant SFRH/BD/21424/2005 from FCT, Portugal.

\section{REFERENCES}

[1] Naimi TS, LeDell KH, Como-Sabetti K, Borchardt SM, Boxrud DJ, Etienne J, Johnson SK, Vandenesch F, Fridkin S, O'Boyle C, Danila RN, Lynfield R (2003) Comparison of community- and health care-associated methicillinresistant Staphylococcus aureus infection. JAMA 290 (22):2976-2984

[2] Patel M (2009) Community-associated meticillin-resistant Staphylococcus aureus infections: epidemiology, recognition and management. Drugs 69 (6):693-716

[3] Graves SF, Kobayashi SD, DeLeo FR (2010) Community-associated methicillinresistant Staphylococcus aureus immune evasion and virulence. J Mol Med 88 (2):109-114 
178 [4] Buck JM, Como-Sabetti K, Harriman KH, Danila RN, Boxrud DJ, Glennen A, 179 Lynfield R (2005) Community-associated Methicillinresistant Staphylococcus 180 aureus, Minnesota, 2000-2003. Emerg Infect Dis 11 (10):1532-1538

181 [5] Division of Healthcare Quality Promotion (DHQP), Centers for Disease Control 182 and Prevention (2005) Community-associated MRSA information for clinicians., 183 http://www.cdc.gov/ncidod/dhqp/ar_mrsa_ca_clinicians.html\#4. Cited June 25, $184 \quad 2010$

185 [6] Aires de Sousa M, Conceição T, Simas C, de Lencastre H (2005) Comparison of 186 genetic backgrounds of methicillin-resistant and -susceptible Staphylococcus 187 aureus isolates from Portuguese hospitals and the community. J Clin Microbiol 188 43 (10):5150-5157

189 [7] Moran GJ, Krishnadasan A, Gorwitz RJ, Fosheim GE, McDougal LK, Carey 190 RB, Talan DA (2006) Methicillin-resistant S. aureus infections among patients in the emergency department. N Engl J Med 355 (7):666-674

192 [8] European Antimicrobial Resistance Surveillance System (2009) EARSS annual 193 report 2008. EARSS, Bilthoven, The Netherlands, http://www.earss.rivm.nl, pp $55-58$

[9] Sá-Leão R, Sanches IS, Couto I, Alves CR, de Lencastre H (2001) Low prevalence of methicillin-resistant strains among Staphylococcus aureus colonizing young and healthy members of the community in Portugal. Microb

199 [10] Tavares DA, Sá-Leão R, Miragaia M, de Lencastre H (2010) Large screening of 200 CA-MRSA among Staphylococcus aureus colonizing healthy young children living in two areas (urban and rural) of Portugal. BMC Infect Dis 10 (1):110 
202

203

204

205

206

207

208

209

210

[11] Clinical Laboratory Standards Institute (2009) Performance Standards for Antimicrobial Susceptibility Testing; Nineteenth Informational Supplement M100-S19, Wayne, Pennsylvania

[12] Okuma K, Iwakawa K, Turnidge JD, Grubb WB, Bell JM, O'Brien FG, Coombs GW, Pearman JW, Tenover FC, Kapi M, Tiensasitorn C, Ito T, Hiramatsu K (2002) Dissemination of new methicillin-resistant Staphylococcus aureus clones in the community. J Clin Microbiol 40 (11):4289-4294

[13] Chung M, de Lencastre H, Matthews P, Tomasz A, Adamsson I, Aires de Sousa M, Camou T, Cocuzza C, Corso A, Couto I, Dominguez A, Gniadkowski M, Goering R, Gomes A, Kikuchi K, Marchese A, Mato R, Melter O, Oliveira D, Palacio R, Sá-Leão R, Santos Sanches I, Song JH, Tassios PT, Villari P (2000) Molecular typing of methicillin-resistant Staphylococcus aureus by pulsed-field gel electrophoresis: comparison of results obtained in a multilaboratory effort using identical protocols and MRSA strains. Microb Drug Resist 6 (3):189-198

[14] McDougal LK, Steward CD, Killgore GE, Chaitram JM, McAllister SK, Tenover FC (2003) Pulsed-field gel electrophoresis typing of oxacillin-resistant Staphylococcus aureus isolates from the United States: establishing a national database. J Clin Microbiol 41 (11):5113-5120

[15] Faria NA, Carriço JA, Oliveira DC, Ramirez M, de Lencastre H (2008) Analysis of typing methods for epidemiological surveillance of both methicillin-resistant and methicillin-susceptible Staphylococcus aureus strains. J Clin Microbiol 46 (1):136-144

[16] Aires de Sousa M, Boye K, de Lencastre H, Deplano A, Enright MC, Etienne J, Friedrich A, Harmsen D, Holmes A, Huijsdens XW, Kearns AM, Mellmann A, Meugnier H, Rasheed JK, Spalburg E, Strommenger B, Struelens MJ, Tenover 
FC, Thomas J, Vogel U, Westh H, Xu J, Witte W (2006) High interlaboratory reproducibility of DNA sequence-based typing of bacteria in a multicenter study. J Clin Microbiol 44 (2):619-621

[17] Crisóstomo MI, Westh H, Tomasz A, Chung M, Oliveira DC, de Lencastre H (2001) The evolution of methicillin resistance in Staphylococcus aureus: similarity of genetic backgrounds in historically early methicillin-susceptible and -resistant isolates and contemporary epidemic clones. Proc Natl Acad Sci U S A 98 (17):9865-9870

[18] Jarraud S, Mougel C, Thioulouse J, Lina G, Meugnier H, Forey F, Nesme X, Etienne J, Vandenesch F (2002) Relationships between Staphylococcus aureus genetic background, virulence factors, agr groups (alleles), and human disease. Infect Immun 70 (2):631-641

[19] Milheiriço C, Oliveira DC, de Lencastre H (2007) Update to the multiplex PCR strategy for assignment of mec element types in Staphylococcus aureus. Antimicrob Agents Chemother 51 (9):3374-3377

[20] Milheiriço C, Oliveira DC, de Lencastre H (2007) Multiplex PCR strategy for subtyping the staphylococcal cassette chromosome mec type IV in methicillinresistant Staphylococcus aureus: 'SCCmec IV multiplex'. J Antimicrob Chemother 60 (1):42-48

[21] Vandenesch F, Naimi T, Enright MC, Lina G, Nimmo GR, Heffernan H, Liassine N, Bes M, Greenland T, Reverdy ME, Etienne J (2003) Communityacquired methicillin-resistant Staphylococcus aureus carrying Panton-Valentine leukocidin genes: worldwide emergence. Emerg Infect Dis 9 (8):978-984 
250 [22] Monday SR, Bohach GA (1999) Use of multiplex PCR to detect classical and newly described pyrogenic toxin genes in staphylococcal isolates. J Clin Microbiol 37 (10):3411-3414

[23] Rasigade JP, Laurent F, Lina G, Meugnier H, Bes M, Vandenesch F, Etienne J, Tristan A (2010) Global Distribution and Evolution of Panton-Valentine Leukocidin-Positive Methicillin-Susceptible Staphylococcus aureus, 1981-2007. J Infect Dis 201:1589-1597

[24] Vorobieva V, Bazhukova T, Hanssen AM, Caugant DA, Semenova N, Haldorsen BC, Simonsen GS, Sundsfjord A (2008) Clinical isolates of Staphylococcus aureus from the Arkhangelsk region, Russia: antimicrobial susceptibility, molecular epidemiology, and distribution of Panton-Valentine leukocidin genes. APMIS 116 (10):877-887

[25] Baranovich T, Zaraket H, Shabana, II, Nevzorova V, Turcutyuicov V, Suzuki H (2010) Molecular characterization and susceptibility of methicillin-resistant and methicillin-susceptible Staphylococcus aureus isolates from hospitals and the community in Vladivostok, Russia. Clin Microbiol Infect 16 (6):575-582

[26] Chheng K, Tarquinio S, Wuthiekanun V, Sin L, Thaipadungpanit J, Amornchai P, Chanpheaktra N, Tumapa S, Putchhat H, Day NP, Peacock SJ (2009) Emergence of community-associated methicillin-resistant Staphylococcus aureus associated with pediatric infection in Cambodia. PLoS One 4 (8):e6630

[27] Fan J, Shu M, Zhang G, Zhou W, Jiang Y, Zhu Y, Chen G, Peacock SJ, Wan C, Pan W, Feil EJ (2009) Biogeography and virulence of Staphylococcus aureus. PLoS One 4 (7):e6216

[28] Pan ES, Diep BA, Charlebois ED, Auerswald C, Carleton HA, Sensabaugh GF, Perdreau-Remington F (2005) Population dynamics of nasal strains of 
methicillin-resistant Staphylococcus aureus - and their relation to communityassociated disease activity. J Infect Dis 192 (5):811-818

[29] Grundmann H, Aanensen DM, van den Wijngaard CC, Spratt BG, Harmsen D, Friedrich AW (2010) Geographic distribution of Staphylococcus aureus causing invasive infections in Europe: a molecular-epidemiological analysis. PLoS Med 7 (1):e1000215

[30] Sattler CA, Mason EO, Jr., Kaplan SL (2002) Prospective comparison of risk factors and demographic and clinical characteristics of community-acquired, methicillin-resistant versus methicillin-susceptible Staphylococcus aureus infection in children. Pediatr Infect Dis J 21 (10):910-917

[31] Le J, Lieberman JM (2006) Management of community-associated methicillinresistant Staphylococcus aureus infections in children. Pharmacotherapy 26 (12): $1758-1770$

[32] LaPlante KL, Rybak MJ, Amjad M, Kaatz GW (2007) Antimicrobial susceptibility and staphylococcal chromosomal cassette mec type in communityand hospital-associated methicillin-resistant Staphylococcus aureus. Pharmacotherapy $27(1): 3-10$

[33] Aires de Sousa M, Bartzavali C, Spiliopoulou I, Sanches IS, Crisóstomo MI, de Lencastre H (2003) Two international methicillin-resistant Staphylococcus aureus clones endemic in a university hospital in Patras, Greece. J Clin Microbiol 41 (5):2027-2032

[34] Aires de Sousa M, Correia B, de Lencastre H (2008) Changing patterns in frequency of recovery of five methicillin-resistant Staphylococcus aureus clones in Portuguese hospitals: surveillance over a 16-year period. J Clin Microbiol 46 (9):2912-2917 
300

301

302

[35] Faria NA, Oliveira DC, Westh H, Monnet DL, Larsen AR, Skov R, de Lencastre H (2005) Epidemiology of emerging methicillin-resistant Staphylococcus aureus (MRSA) in Denmark: a nationwide study in a country with low prevalence of MRSA infection. J Clin Microbiol 43 (4):1836-1842

[36] Sá-Leão R, Santos Sanches I, Dias D, Peres I, Barros RM, de Lencastre H (1999) Detection of an archaic clone of Staphylococcus aureus with low-level resistance to methicillin in a pediatric hospital in Portugal and in international samples: relics of a formerly widely disseminated strain? J Clin Microbiol 37 (6):1913-1920

[37] Diep BA, Chan L, Tattevin P, Kajikawa O, Martin TR, Basuino L, Mai TT, Marbach H, Braughton KR, Whitney AR, Gardner DJ, Fan X, Tseng CW, Liu GY, Badiou C, Etienne J, Lina G, Matthay MA, DeLeo FR, Chambers HF (2010) Polymorphonuclear leukocytes mediate Staphylococcus aureus PantonValentine leukocidin-induced lung inflammation and injury. Proc Natl Acad Sci U S A 107 (12):5587-5592

[38] Daskalaki M, Rojo P, Marin-Ferrer M, Barrios M, Otero JR, Chaves F (2010) Panton-Valentine leukocidin-positive Staphylococcus aureus skin and soft tissue infections among children in an emergency department in Madrid, Spain. Clin Microbiol Infect $16(1): 74-77$

[39] Wu D, Wang Q, Yang Y, Geng W, Yu S, Yao K, Yuan L, Shen X (2010) Epidemiology and molecular characteristics of community-associated methicillin-resistant and methicillin-susceptible Staphylococcus aureus from skin/soft tissue infections in a children's hospital in Beijing, China. Diagn Microbiol Infect Dis 67 (1):1-8 
[40] Miller LG, Perdreau-Remington F, Bayer AS, Diep B, Tan N, Bharadwa K, Tsui J, Perlroth J, Shay A, Tagudar G, Ibebuogu U, Spellberg B (2007) Clinical and epidemiologic characteristics cannot distinguish community-associated methicillin-resistant Staphylococcus aureus infection from methicillinsusceptible $S$. aureus infection: a prospective investigation. Clin Infect Dis 44 (4):471-482

\section{FIGURE LEGENDS:}

Fig. 1 Antimicrobial susceptibility of the 38 S. aureus isolates to a panel of 10 antibiotics. Abbreviations: S, susceptible; R, resistant; na, not available; OXA, oxacillin; PEN, penicillin; AMC, amoxicillin-clavulanic acid; CIP, ciprofloxacin; ERY, erythromycin; CLI, clindamycin; TET, tetracycline; GEN, gentamicin; SXT, trimethoprim-sulfamethoxazole; VAN, vancomycin. All the resistant phenotypes observed for clindamycin mean inducible resistance, determined by D-test [11].

Fig. 2 Virulence gene determinants of the eight clonal lineages. The totality of the isolates was tested for 11 virulence genes. Abbreviations: PVL, Panton Valentine leukocidin; LukM, leukocidin M; LukDE, leukocidins D and E; $\beta$-hemol, $\beta$ hemolysin; $\gamma$-hemol, $\gamma$-hemolysin; $\gamma$-hemol var, $\gamma$-hemolysin variant; ETA, ETB, ETD, exfoliative toxins A, B and D; SEL, SEP, staphylococcal enterotoxins L and P.

Table 1 Molecular characterization and clinical presentation of the clonal lineages found among the 38 S. aureus isolates recovered during the 15-month study period.

\begin{tabular}{|c|c|c|c|c|c|c|c|c|c|}
\hline \multirow{2}{*}{ No. of isolates } & \multirow{2}{*}{$\begin{array}{c}\text { PFGE types } \\
\text { (No. of } \\
\text { subtypes) }\end{array}$} & \multirow{2}{*}{$\begin{array}{l}\text { spa } \\
\text { type }^{\text {a }}\end{array}$} & & & \multirow{2}{*}{$\begin{array}{c}\text { SCCmec } \\
\text { type }\end{array}$} & \multirow{2}{*}{ PVL } & \multirow{2}{*}{$\begin{array}{l}a g r \\
\text { type }\end{array}$} & \multirow{2}{*}{$\begin{array}{l}\text { Related } \\
\text { clone }^{\mathrm{c}}\end{array}$} & \multirow{2}{*}{$\begin{array}{l}\text { Clinical } \\
\text { presentation } \\
\text { (No. of }\end{array}$} \\
\hline & & & ST & $\mathrm{CC}$ & & & & & \\
\hline
\end{tabular}


isolates)

\begin{tabular}{|c|c|c|c|c|c|c|c|c|c|}
\hline 19 & A (8) & $\mathrm{t} 159$ & 121 & 121 & MSSA & - & IV & & $\begin{array}{l}\text { cellulitis (9), } \\
\text { cutaneous } \\
\text { abscess (3), } \\
\text { impetigo (1), } \\
\text { wound (1), } \\
\text { nasal swab (5) }\end{array}$ \\
\hline 6 & B (4) & $\mathrm{t} 318$ & 30 & 30 & MSSA & + & III & $\begin{array}{l}\text { South } \\
\text { Westh } \\
\text { Pacificic }\end{array}$ & $\begin{array}{l}\text { cutaneous } \\
\text { abcess (6) }\end{array}$ \\
\hline 3 & C (3) & t576 & 45 & 45 & MSSA & - & I & Berlin & $\begin{array}{l}\text { cutaneous } \\
\text { abscess (2), } \\
\text { celullitis (1) }\end{array}$ \\
\hline 2 & $\mathrm{D}(2)$ & $\mathrm{t} 535$ & 5 & 5 & IVc & - & II & Paediatric & $\begin{array}{l}\text { impetigo (1), } \\
\text { bacteremia (1) }\end{array}$ \\
\hline 1 & D (1) & $\mathrm{t} 311$ & 5 & 5 & MSSA & + & II & Paediatric & $\begin{array}{l}\text { cutaneous } \\
\text { abscess (1), }\end{array}$ \\
\hline 3 & E (2) & $\mathrm{t} 355$ & 152 & 152 & MSSA & + & I & & $\begin{array}{l}\text { cutaneous } \\
\text { abscess (1), } \\
\text { cellulitis (1), } \\
\text { adenophlegmon } \\
\text { (1) }\end{array}$ \\
\hline 2 & $F(2)$ & $\mathrm{t} 127$ & 1 & 1 & MSSA & + & III & & $\begin{array}{l}\text { cutaneous } \\
\text { abscess (1), } \\
\text { pustule (1) }\end{array}$ \\
\hline 1 & G & t044 & 80 & 80 & IVc & + & III & European & pustule (1) \\
\hline 1 & $\mathrm{H}$ & t084 & 582 & 15 & MSSA & - & IV & & impetigo (1) \\
\hline
\end{tabular}

$345{ }^{a}$ Ridom nomenclature (http://spaserver.ridom.de/).

$346 \quad{ }^{\mathrm{b}}$ MLST - multilocus sequence typing, ST - sequence type; CC - clonal complex, defined by 347 eBurst v3 assessed on 12 April 2010.

$348{ }^{\mathrm{d}}$ Common designation of community or hospital associated MRSA or MSSA clones. 